\title{
PENGELOLAAN ACARA "BANDUNG LAUTAN SEPEDA" OLEH BIRO HUMAS DAN PROTOKOL SEKRETARIAT DAERAH PROVINSI JAWA BARAT
}

\author{
Putri Meysha Nabila Fauzziya $^{1}$, Aat Ruchiat Nugraha ${ }^{2 *}$ \\ ${ }^{1,2}$ Universitas Padjadjaran \\ Jl. Raya Bandung Sumedang KM.21, Hegarmanah, Kec. Jatinangor, \\ Kabupaten Sumedang, Jawa Barat 45363, INDONESIA \\ * Penulis korespondensi; Email: ruchiat@unpad.ac.id
}

\begin{abstract}
ABSTRAK
Salah satu ciri keberhasilan pelayanan publik yang dilakukan oleh suatu organisasi adalah dalam bentuk penyampaian informasi dan penyelenggaraan suatu kegiatan yang bermanfaat bagi para pemangku kepentingan. Penyampaian informasi dan penyelenggaraan kegiatan tersebut merupakan bagian dari komunikasi publik yang harus dilakukan oleh bagian humas dari suatu organisasi. Hal inilah yang dilakukan oleh Biro Humas dan Protokol Sekretariat Daerah Provinsi Jawa Barat yang memiliki fungsi sebagai garda terdepan untuk memberikan informasi melalui berbagai media publikasi dengan strategi yang telah ditentukan. Salah satu bentuk strategi yang dilakukan adalah PR event dan media relations yang dikemas dalam kegiatan yang bertemakan "Bandung Lautan Sepeda". Artikel ini membahas mengenai bagaimana isi pesan komunikasi yang disampaikan dalam kegiatan "Bandung Lautan Sepeda" serta bagaimana penggunaan media publikasinya. Penelitian ini menggunakan metode kualitatif dengan pendekatan penelitian berdasarkan deskriptif melalui pengumpulan data yang dilakukan dengan cara wawancara, observasi lapangan, dan studi pustaka. Hasil penelitian pada kegiatan "Bandung Lautan Sepeda" menunjukkan bahwa isi pesan yang disampaikan pada poster kegiatan mengandung kalimat-kalimat yang bersifat persuasif . Sedangkan jenis media publikasi yang digunakan adalah media below the line seperti spanduk, poster, backdrop, dan words of mouth.
\end{abstract}

Kata kunci: Hubungan masyarakat; kegiatan humas; strategi media.

\begin{abstract}
One of the characteristics of the success of public services carried out by an organization is in the form of delivering information and organizing an activity that is beneficial to stakeholders. Submitting information and organizing these activities is part of public communication that must be carried out by the public relations department of an organization. Is done by the Public Relations and Protocol Bureau of the Regional Secretariat of West Java Province which has the function as the front guard to provide information through various media publications with a deliberate strategy. The form of undertaken strategy is public relations events and media relations which packaged in activities with the theme "Bandung Ocean Bike". This article discusses how the contents of the communication message delivered in the "Bandung Lautan Sepeda" activity and how to use its publication media. This study uses a qualitative method with a descriptive-based research approach through data collection conducted by interviews, field observations, and literature studies. The results of the research on the "Bandung Ocean of Bicycles" activity showed that the message content conveyed on the activity poster contained persuasive sentences while the type of media publication used is below the line media such as banners, posters, backdrops, and word of mouth.
\end{abstract}

Keywords: Public relations; public relations event; media strategy.

\section{PENDAHULUAN}

Dewasa ini kehidupan sosial sudah berada di era digital dan sudah memasuki era post-digital dimana informasi bisa diakses melalui berbagai media dan tidak ada batasan. Sehingga dalam perkembangan teknologi dan masyarakat yang begitu maju, media merupakan salah satu kebutuhan manusia untuk mendapatkan informasi (Goenawan, 2008). Keberadaan Public Relations Officer (PRO) saat ini tidak bisa sekadar mengerjakan siaran pers, monitoring media cetak, dan menjaga citra perusahaan saja, akan tetapi dituntut lebih dari itu semua. Humas sebagai jembatan penghubung informasi antara organisasi dengan publiknya memiliki kemampuan untuk dapat menyampaikan isi pesan organisasi sesuai dengan karakter media yang diinginkannya. Penyampaian pesan tersebut harus dapat dilaksanakan berdasarkan pada strategi publikasi yang sudah direncanakan. Tanpa hubungan yang efektif antara suatu organisai 
atau lembaga dengan publiknya maka tidak akan dapat melakukan kegiatan-kegiatannya dengan berhasil, karena pada dasarnya suksesnya suatu organisasi atau lembaga adalah atas dasar peran pihak lain yang terjalin secara harmonis (Herdiana \& Khoiruddin, 2016).

Adanya penyampaian pesan dengan menggunakan strategi publikasi dapat memberikan kemudahan bagi PRO untuk memetakan informasi yang akan disampaikan ke berbagai publik sasaran kegiatan dari suatu organisasi. Strategi kehumasan dalam bidang publikasi memiliki peranan penting bagi organisasi dalam upaya mewujudkan visi dan misi perusahaan yang secara maksimal. Sebagaimana hal ini dipertegas oleh (Herlina, 2015) yang menyatakan bahwa humas memiliki peranan penting dalam setiap lembaga karena humas menjadi salah satu strategi dalam membentuk citra suatu lembaga, baik itu citra positif maupun citra negatif. Strategi kehumasan dengan melaksanakan suatu kegiatan yang dilakukan merupakan dua hal yang berjalan beriringan guna mencapai tujuan suatu organisasi. Strategi pada hakikatnya adalah perencanaan untuk mencapai suatu tujuan. Sedangkan untuk pelaksanaan kegiatan di suatu organisasi, sekarang tidak lagi hanya menjadi ranah tugas pekerjaan seorang event organizer saja, namun menjadi bagian keahlian dasar bagi seorang PRO dalam mengelola sebuah acara yang merupakan salah satu bagian kegiatan kehumasannya dalam menyampaikan sebuah informasi kepada publiknya melalui program-program kerja yang terencana. (Soemirat \& Ardianto, 2007) menyebutkan bahwa salah satu kompetensi untuk dapat menjadi seorang humas yang profesional adalah kemampuan untuk mengorganisasikan suatu kegiatan (ability to organize). Melalui pelaksanaan sebuah kegiatan atau acara (event) yang dapat dilakukan oleh seorang humas profesional secara baik dapat menjadi salah satu faktor pendukung informasi yang muncul pada pemberitaan di media massa yang dapat menjadi nilai citra suatu organisasi dihadapan publiknya.

Terkait dengan nilai citra suatu lembaga, Sekretariat Daerah Provinsi Jawa Barat sebagai salah satu struktur organisasi di lembaga pemerintahan provinsi Jawa Barat memiliki peran dan fungsi komunikasi publik yang dilakukan oleh humas yang di mana secara struktural berada dibawah pimpinan Kepala Biro Humas dan Protokol yang memiliki tugas pokok menyelenggarakan koordinasi, pembinaan, pengendalian, fasilitasi dan pelaksanaan fungsi penunjang urusan pemerintahan pada aspek humas dan protokol yang meliputi pelayanan media dan informasi, publikasi, peliputan dan dokumentasi, serta keprotokolan, menyelenggarakan tugas dekonsentrasi sampai dengan dibentuk sekretariat Gubernur sebagai wakil Pemerintah Pusat serta melaksanakan tugas pembantuan sesuai bidang tugasnya.

Dalam rangka menjaga hubungan yang harmonis antara lembaga pemerintahan dengan para pemangku kepentingan, Humas Pemerintah Provinsi Jawa Barat secara rutin menyelenggarakan suatu kegiatan yang melibatkan berbagai sektor pemangku kepentingan. Beberapa kegiatan yang diselenggarakan di antaranya acara penghargaan, acara perayaan, hingga acara peringatan. Salah satu kegiatan peringatan yang diselenggarakan setiap tahunnya oleh Biro Humas dan Protokol adalah Upacara Peringatan Hari Pahlawan, yang merupakan momentum untuk mengingatkan kembali mengenai jasa dan semangat juang para pahlawan Republik Indonesia kepada masyarakat Jawa Barat khususnya. Kegiatan ini termasuk event tahunan yang berbentuk peringatan dalam skala nasional.

Acara peringatan Hari Pahlawan ini rutin diadakan dengan mengambil tempat di Taman Makam Pahlawan dan Gedung Sate. Acara rutin ini digelar dengan mempertimbangkan rasa hormat terhadap para pahlawan yang sudah memperjuangkan kemerdekaan Indonesia yang perlu untuk dimaknai lebih jauh oleh berbagai kelompok kepentingan agar tercipta kondisi masyarakat yang memiliki jiwa patriot. Tugas untuk dapat menjaga harmonisasi dengan masyarakat mengenai dukungan terhadap programprogram pemerintah yang sedang dilaksanakan maupun akan dilaksanakan merupakan bagian dari Tupoksi Setda Pemprov Jawa Barat. Adanya bentuk dukungan masyarakat pada pemerintahan merupakan salah satu indikator keberhasilan yang diemban oleh Sekretariat Daerah Pemerintah Provinsi Jawa Barat dalam menjalankan salah satu tugas rutinitasnya di lembaga pemerintahan dalam bentuk penyampaian informasi dalam suatu event. Sehingga menurut (Awaliah, 2012) melalui pemilihan tema yang tepat dari sebuah event akan mampu menempatkan kedudukan citra lembaga di mata masyarakat.

Terdapat hal yang membedakan dari tahun-tahun sebelumnya pada acara peringatan Hari Pahlawan pada tahun ini yang diselenggarakan oleh Setda Pemprov Jawa Barat, yaitu adanya acara tambahan yang bukan sekedar upacara resmi namun menyelenggarakan event yang berskala nasional dalam bentuk yaitu "Bandung Lautan Sepeda" yang terselenggara atas kerjasama Kodam III Siliwangi, 
Pemerintah Provinsi Jawa Barat, dan Polda Jawa Barat. Event "Bandung Lautan Sepeda" tersebut mengusung tema semangat pahlawan di dadaku, yang bertujuan untuk menyampaikan pesan mengenai semangat untuk membangun negara dan terus membangun negara kepada seluruh masyarakat Indonesia.

Bentuk kegiatan pada acara "Bandung Lautan Sepeda" ini adalah bersepeda bersama para pimpinan Muspida Pemerintahan Jawa Barat dan masyarakat yang mengelilingi kota Bandung. Pada acara tahun ini, turut hadir Presiden Republik Indonesia Joko Widodo yang menitipkan pesan melalui kegiatan ini agar masyarakat memiliki semangat berinovasi, semangat berkreasi, semangat berkarya, semangat bekerja, dan semangat optimistis. Pada umumnya, kegiatan utama pada acara "Bandung Lautan Sepeda" adalah bersepeda bersama masyarakat sekitar dan komunitas sepeda yang diikuti lebih dari 15.000 peserta dari TNI, Polri, ASN, Komunitas Sepeda, Siswa dan masyarakat umum yang dilepas dan diikuti oleh Presiden Republik Indonesia dengan tanpa dipungut biaya pendaftaran.

Tujuan kegiatan event "Bandung Lautan Api" adalah untuk kembali menyampaikan dan menunjukkan keteladanan para pahlawan bangsa kepada masyarakat sekitar yang dapat menjadi modal bagi segenap komponen bangsa dalam menjaga, memelihara, dan memperkokoh persatuan dalam membangun negeri. Pada tahun 2018 ini, diikuti oleh Kepala Staf Kepresidenan Moeldoko, Panglima TNI Marsekal Hadi Tjahjanto, dan Kapolri Jenderal Tito Karnavian. Suasana pada acara ini pun didominasi nuansa tahun 45-an, yang terlihat dari pakaian para peserta yang meniru gaya masyarakat dan para pahlawan dan sepeda yang digunakan.

Pada setiap acara dan program yang dijalankan oleh Sekretariat Daerah Provinsi Jawa Barat, umumnya selalu dipublikasikan di media sosial resmi Humas Pemerintah Provinsi Jawa Barat, khususnya pada platform instagram. Selain membagikan informasi mengenai acara maupun program yang sedang berlangsung dan yang akan dilaksanakan atau sudah dilaksanakan, pada akun tersebut juga secara aktif membagikan informasi seputar Jawa Barat. Adapun jenis informasi yang dibagikan dalam instagram tersebut seringkali berisikan tentang informasi budaya dan sumber daya alam yang ada di Jawa Barat.

Acara "Bandung Lautan Sepeda" 2018 diselenggarakan atas gagasan dari Kodam III Siliwangi yang merupakan bagian dari rangkaian peringatan Hari Pahlawan di Jawa Barat yang diselenggarakan setiap tahunnya oleh Sekretariat Daerah Provinsi Jawa Barat. Tentu saja acara yang melibatkan lembagalembaga besar, komunitas, hingga masyarakat ini tidak akan diketahui massa yang ditentukan tanpa publikasi melalui media yang memberikan informasi baik mengenai acara maupun informasi tentang pelayanan publik pada hari tersebut.

Pada acara "Bandung Lautan Sepeda" ini Sekretariat Daerah Provinsi Jawa Barat membagi tugas dengan penggagas acara "Bandung Lautan Sepeda" yaitu Kodam III Siliwangi mengenai informasi dari persiapan hingga informasi acara "Bandung Lautan Sepeda" di hari acara. Berbagai media platform digunakan oleh penyelenggara dari media cetak hingga media online, terutama media lokal Bandung. Terkait dengan penyelenggaraan event skala nasional, maka diperlukan keterlibatan langsung dari otoritas setempat untuk dapat mensukseskan acara tersebut secara baik. Adapun peran Sekretariat Daerah Provinsi Jawa Barat sebagai pemerintah mestinya tidak hanya sekedar memberikan informasi umum mengenai suatu event kepada masyarakat melainkan juga harus dapat memberikan informasi sampai pada ranah teknis seperti informasi mengenai jalur yang akan digunakan sehingga masyarakat yang akan melalui jalan tersebut bisa mengetahui informasi alur jalan yang akan dilintasi oleh para peserta sehingga masyarakat dapat mengantisipasinya. Informasi mengenai fasilitas publik yang digunakan pada acara tersebut tidak banyak dipublikasikan di media, umumnya para awak media menginformasikan jalur yang akan dilalui dan jam mulai acara, tetapi ada satu media yang menginformasikan bahwa adanya penutupan jalan sementara yaitu media lokal dari Bandung.

Meskipun acara ini dilaksanakan di Bandung dan bukan di ibu kota negara, adanya media lokal, regional, maupun nasional yang meliput dan hadir pada saat acara "Bandung Lautan Sepeda" dilaksanakan dikarenakan bisa terkait dengan momentum jelang tahun politik pada tahun 2019. Momentum politik tersebut dicitrakan dengan hadirnya tokoh RI 1 dan Jabar 1 yang berada di satu tempat dan acara sehingga para media banyak menyoroti kedua tokoh tersebut dari penampilan pada saat acara, kedatangan, hingga acara selesai.

Kehadiran tokoh utama bangsa menjadikan berbagai media massa yang meliput turut menyebarluaskan berita setelah acara ini berlangsung. Di mana isi berita 
menyampaikan tentang bagaimana para peserta yang hadir banyak mengenakan pakaian pahlawan-pahlawan di Indonesia yang tidak dibatasi umur. Adapun pesan utama dari event skala nasional ini adalah semangat pahlawan di dadaku, yang bertujuan untuk menyampaikan pesan semangat untuk membangun negara, untuk terus membangun negara telah terpublikasikan di berbagai media massa tingkat lokal, regional maupun nasional.

Berdasarkan latar belakang informasi yang telah dipaparkan sebelumnya, maka penulis merasa tertark untuk membahas mengenai bagaimana Biro Humas Setda Pemerintan Provinsi Jawa Barat dalam mengelola event yang bertarap nasional dapat berjalan dengan baik dan lancar.

\section{METODE PENELITIAN}

Penelitian Pengelolaan Acara "Bandung Lautan Sepeda" Oleh Biro Humas Dan Protokol Sekretariat Daerah Provinsi Jawa Barat ini merupakan penelitian dengan menggunakan metode kualitatif deskriptif. Penelitian deskriptif adalah penelitian yang berusaha mendeskripsikan suatu gejala peristiwa kejadian yang terjadi saat sekarang yang memusatkan perhatian pada masalah aktual sebagaimana adanya pada saat penelitian berlangsung melalui penelitian deskriptif peneliti berusaha mendeskripsikan peristiwa dan kejadian yang menjadi pusat perhatian tanpa memberikan perlakuan khusus terhadap peristiwa tersebut (Noor, 2011). Dengan demikian penelitian ini menggunakan metode deskriptif yang dimaksudkan untuk meneliti dan menjabarkan setiap fenomena-fenomena yang terjadi pada setiap proses dan realitas yang terjadi di lapangan saat peneliti melakukan pengamatan langsung melalui kegiatan job training.

Teknik pengumpulan data pada penelitian ini penulis melakukan dengan teknik wawancara, observasi lapangan, dan studi pustaka (dokumentasi). Peneliti melakukan pencarian data dengan melakukan wawancara mendalam dengan sumber data primer dan melakukan perbandingan dengan data sekunder. Hal ini diperlukan agar mendapat data berupa fakta yang sesuai dengan realita. Sedangkan pada wawancara peneliti melakukan wawancara dengan pihak biro humas sub bagian keprotokolan Setda Provinsi Jawa Barat guna mengumpulkan data-data secara langsung sebagai sumber utama di lapangan. Penulis mengajukan pertanyaan secara terbuka kepada narasumber untuk menggali permasalahan secara mendalam yaitu kepada pihak-pihak yang memenuhi kriteria peneliti yang memahami mengenai kegiatan pelaksanaan Upacara Hari Pahlawan 2018 dan Bandung Lautan Sepeda 2018 di kota Bandung. Penulis mendengarkan secara teliti dan mencatat apa yang dikemukakan narasumber dan pihak-pihak yang terkait. Hasil dari wawancara yang dilakukan peneliti disusun menjadi data tertulis yang dapat dijadikan bahan pembahasan penelitian.

Selain wawancara dan observasi lapangan, peneliti mengunakan teknik pengumpulan data melalui pemanfaatan dokumen karena menurut (Sugiyono, 2010) studi dokumen merupakan pelengkap dari penggunaan metode wawancara dan observasi. Metode dokumentasi dalam penelitian ini dimaksudkan untuk memperoleh data dengan cara dokumentasi, yaitu mempelajari dokumen yang berkaitan dengan seluruh data yang diperlukan dalam penelitian. Peneliti mengambil beberapa referensi dari buku yang berkaitan dengan metode, peristiwa dan konsep yang sesuai dengan penelitian ini untuk menunjang kelengkapan data penelitian. Di dalam melaksanakan metode dokumentasi, peneliti menyelidiki benda-benda tertulis seperti pedoman tugas pokok biro humas sub keprotokolan yang relevan dengan kepentingan penelitian. Selain itu, penulis juga menggunakan dokumen yang berasal dari pemberitaan media surat kabar dan internet yang berkaitan dengan kegiatan "Bandung Lautan Sepeda", serta sumber dari berbagai literasi ilmiah untuk dijadikan acuan dalam proses penelitian.

Menurut Ardianto (2014) observasi lapangan (field observation) adalah kegiatan yang setiap saat dilakukan dengan kelengkapan panca indera yang dimiliki. Observasi difokuskan untuk mendeskripsikan dan menjelaskan fenomena. Menurut Spradley dalam Susan Stainback fenomena ini mencakup interaksi diantara subjek yang diteliti sehingga metode ini memiliki keunggulan yakni mempunyai bentuk data interaksi dan percakapan. Sugiyono (2010) membagi observasi menjadi empat, yaitu passive participation, moderate participation, active participation dan complete participation. Dalam penelitian ini peneliti menggunakan active participation (observasi aktif) dimana peneliti berpartisipasi dan terlibat langsung dalam acara tersebut dan melakukan pengamatan langsung di lapangan untuk meneliti dan dapat membandingkan data lapangan dengan sumber lainnya yang disebut dengan observasi partisipatif. Kemudian peneliti mencatat hasil pengamatan tersebut untuk mengetahui apa yang sebenarnya terjadi. Penulis berperan aktif dalam kegiatan acara tersebut sebagai staff biro protokol sub acara dari proses perencanaan hingga evaluasi. 


\section{HASIL DAN PEMBAHASAN}

Pada kegiatan "Bandung Lautan Sepeda" ini Sekretariat Daerah Provinsi Setda Jabar mengemas pesan yang akan disampaikan kepada targetnya agar tersampaikan sesuai apa yang direncanakan, salah satunya dengan menyebarkan informasi melalui media. Pesan-pesan tersebut disampaikan oleh para tokoh publik yang dapat menambah kredibilitas pesan yang ingin disampaikan melalui kegiatan "Bandung Lautan Sepeda" yang juga mendorong antusiasme masyarakat sekitar yaitu dengan membuat kegiatan yang melibatkan tokoh nomer satu di Jawa Barat dan di Indonesia, yaitu Gubernur Jawa Barat dan Presiden Republik Indonesia. Kegiatan "Bandung Lautan Sepeda" ini bukan diadakan di Ibu Kota Negara, namun antusias masyarakat yang besar terlihat dari banyaknya jumlah peserta yang berkontribusi. Kondisi ini seiring dengan apa yang dinyatakan oleh (Kotler \& Amstrong, 2006), yang menyatakan bahwa kegiatan public relations memiliki tujuan untuk membangun kesadaran, membangun kredibilitas, mendorong penyalur dan mengurangi biaya promosi. Tujuan diadakannya kegiatan "Bandung Lautan Sepeda" ini adalah untuk menjaga semangat juang para masyarakat sekitar, dimana Sekretariat daerah Provinsi Jawa Barat sebagai pusat pemerintahan mengemban tugas untuk dapat menjaga harmonisasi dengan masyarakat mengenai dukungan terhadap pemerintah Indonesia untuk menyampaikan pesan semangat untuk membangun negara, untuk terus membangun negara.

Peran dan fungsi Biro Humas dan Protokol Pemprov Jabar pada kegiatan "Bandung Lautan Sepeda" sejalan dengan tugas pokok dalam pelayanan informasi, meliputi koordinasi dan fasilitasi penyelenggaraan pelayanan informasi dan informasi publik dengan bekerjasama dengan instansi setempat yaitu Polda Jabar dan Kodam III Siliwangi yang berada di lingkup Sekretariat Daerah Provinsi Jawa Barat, khususnya publikasi kepada media. Khususnya Biro Humas dan Protokol Pemprov Jabar adalah pihak yang melakukan monitoring media setelah Kodam III Siliwangi.

Melalui pertemuan guna melakukan koordinasi Biro Humas dan Protokol Pemprov Jabar menjadi penghubung dalam penyampaian informasi dari setiap lembaga yang terlibat dan mengumpulkan informasi mengenai informasi tersebut dari berbagai pihak yang selanjutnya berperan sebagai pengambil keputusan yang sebelumnya dicapai melalui diskusi didalam pertemuan dengan berbagai pihak terutama peng- gagas acara "Bandung Lautan Sepeda" yaitu Kodam III Siliwangi. Lasswell menyampaikan bahwa dalam menyampaikan pesan adalah dengan memerhatikan who says; what, in which channel, to whom, with what effect (Effendy, 2002). Untuk mendukung terciptanya proses penyampaian pesan dalam kegiatan "Bandung Lautan Sepeda" memiliki unsurunsur yang terlibat komunikator, pesan, media, komunikan, dan efek.

Setda Jabar khususnya Biro Humas dan Protokol memiliki fungsi sebagai komunikator atau penghubung antara organisasi atau lembaga yang terlibat dalam acara "Bandung Lautan Sepeda" yang secara tidak langsung juga menjalankan peran Humas yaitu berupaya membina hubungan yang positif dan saling menguntungkan dengan pihak publiknya.dimana hal ini dapat membentuk corporate image, khususnya Pemerintahan Provinsi Jawa Barat di masyarakat dan instansi sekitarnya. Pesan yang ingin disampaikan melalui kegiatan "Bandung Lautan Sepeda" ialah menyampaikan dan menunjukkan keteladanan para pahlawan kepada masyarakat sekitar yang dapat menjadi modal bagi segenap komponen bangsa dalam menjaga, memelihara, dan memperkokoh persatuan dalam membangun negeri. Humas dan Protokol Setda Jabar memaksimalkan penggunaan media above dan below the line dalam penyampaian pesannya, komunikan pada kegiatan ini adalah masyarakat khususnya masyarakat Bandung, efek yang diharapkan adalah agar masyarakat dapat ikut serta dalam kegiatan "Bandung Lautan Sepeda".

Acara yang juga diikuti oleh Kepala Staf Kepresidenan Moeldoko, Panglima TNI Marsekal Hadi Tjahjanto, dan Kapolri Jenderal Tito Karnavian inipun didominasi nuansa tahun 45-an, yang terlihat dari pakaian para peserta yang meniru gaya masyarakat dan para pahlawan dan sepeda yang digunakan. Hal tersebut sesuai dengan tema dari acara "Bandung Lautan Sepeda" yaitu semangat pahlawan di dadaku, yang bertujuan untuk menyampaikan pesan semangat untuk membangun negara, untuk terus membangun negara yang merupakan isi pesan yang disampaikan melalui kegiatan "Bandung Lautan Sepeda" untuk mendekatkan masyarakat dan lembaga sekitar untuk memiliki hubungan yang harmonis.

Penyampaian informasi ini dilakukan secara persuasif yang ditandai dengan kalimat-kalimat ajakan yang terdapat dalam media publikasi. Schramm mengemukakan bahwa proses persuasi adalah proses komunikasi yang biasanya terdiri dari pengenalan informasi yang kemudian menggiring penerima untuk meng- 
ubah persepsi terhadap lingkungan. Cara yang paling tepat untuk mempengaruhi masyarakat melalui pendekatan humas adalah persuasi (Putra, 1999). Pesan yang disampaikan pada kegiatan "Bandung Lautan Sepeda" merupakan isi pesan yang persuasif dimana pihak penyelenggara acara mengajak masyarakat Bandung untuk bersepeda bersama mengelilingi Bandung karena inti dari acara "Bandung Lautan Sepeda" ini adalah mengajak masyarakat sekitar yang nantinya akan menjadi peserta utama dalam kegiatan "Bandung Lautan Sepeda".

Isi pesan yang ingin disampaikan dapat terlihat pada publikasi acara yang merupakan poster sebagai gambar 1.

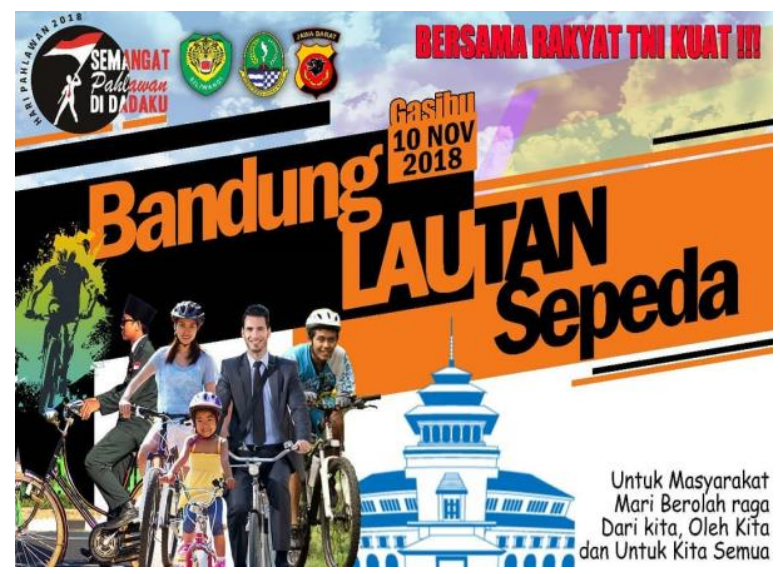

Gambar 1. Poster Bandung Lautan Sepeda 1

Pada kegiatan "Bandung Lautan Sepeda" ini salah satu media yang digunakan berbentuk poster digital yang dipublikasikan melalui berbagai media, terutama media lokal Bandung. Pada poster tersebut menyantumkan nama acara yaitu Bandung Lautan Sepeda dengan visualisasi gambar orang bersepeda dari mulai anak kecil, remaja hingga orang dewasa yang terlihat seperti pekerja. Melalui visualisasi ini dapat tersampaikan pesan bahwa acara ini merupakan kegiatan lari yang berlokasi di Bandung yang dapat diikuti oleh semua kalangan yaitu dari anak-anak, remaja maupun dewasa.

Lokasi atau tempat pelaksanaan kegiatan "Bandung Lautan Sepeda" divisualisasikan dengan adanya gambar gedung sate, akan tetapi hal ini dirasa bersifat ambigu karena gedung sate merupakan pusat pemerintahan di Jawa Barat yang dimana Setda Jabar merupakan salah satu penyelenggara yang bekerjasama dengan Kodam III Siliwangi dan Polda Jabar, hal tersebut terlihat dari logo yang tercantum pada bagian kiri atas poster. Selain logo lembaga, pada bagian kiri atas poster juga tercantum logo kegiatan
Hari Pahlawan tahun 2018 yang memberikan makna bahwa kegiatan Bandung Lautan Sepeda ini merupakan bagian dari acara memperingati Hari Pahlawan.

Pada logo Hari Pahlawan tahun 2018 tersebut tersampaikan tema kegiatan hari pahlawan tahun 2018 yaitu "semangat pahlawan di dadaku" dimana tema tersebut pun menjadi tema besar dari kegiatan "Bandung Lautan Sepeda". Selain, terdapat logo lembaga yang bekerjasama dalam menyelenggarakan kegiatan "Bandung Lautan Sepeda", terdapat pula teks kutipan pada bagian kanan atas yaitu "Bersama Rakyat TNI Kuat" hal ini menyampaikan pesan sesuai dengan tujuan dari acara "Bandung Lautan Sepeda" bahwa masyarakat dapat mempercayai lembaga pemerintahan yang berjuang untuk membela dan mempertahankan negara.

Untuk tanggal dari pelaksanaan acara pun tervisualisasikan dengan jelas disamping nama kegiatan sehingga mudah ditangkap oleh target publik acara "Bandung Lautan Sepeda". Dalam poster tersebut juga terdapat pesan persuasi yang disampaikan melalui teks "Untuk Masyarakat, Mari Berolah raga Dari kita, Oleh Kita dan Untuk Kita Semua", upaya persuasi terlihat dari kata-kata yang bersifat mengajak yaitu "Mari" yang ditujukan kepada target sasaran dari kegiatan "Bandung Lautan Sepeda" yaitu masyarakat umum untuk berolah raga yang merupakan jenis kegiatan pada acara ini.

Pada poster kegiatan "Bandung Lautan Sepeda" ini menggunakan warna dasar putih yang dipadukan dengan berbagai warna. Warna hitam dan oranye digunakan pada dasar penulisan untuk nama kegiatan dan tanggal pelaksanaan kegiatan. Pemilihan warna yang kontras ini tidak akan membuat target bias dalam membaca informasi dalam kata lain perpaduan warna dasar tersebut sesuai dengan teks informasi yang tercantum pada poster sehingga mudah dibaca. Komposisi konten dalam penempatan informasi pada poster pun proporsional dan tidak berlebihan, dimana inti dari informasi yaitu nama kegiatan, jenis kegiatan dan waktu ditempatkan di tengah poster sehingga menjadi pusat perhatian saat melihat visualisasi poster tersebut.

Pada poster tersebut ada informasi yang tidak tersampaikan yaitu bagaimana cara masyarakat untuk mengikuti kegiatan "Bandung Lautan Sepeda" atau terkait registrasi peserta dan acara apa saja yang akan berlangsung. Kejelasan informasi terkait dua hal tersebut mestinya dapat menarik massa untuk memahami kegiatan yang akan masyarakat ikuti. Selain itu, 
masyarakat dapat lebih tertarik apabila diberitahukan mengenai hadiah-hadiah yang diberikan setelah kegiatan bersepeda oleh pihak penyelenggara. Akan tetapi Informasi yang disampaikan dalam satu poster dengan konten yang ada tersebut dirasa kurang maksimal.

Poster "Bandung Lautan Sepeda" ini tidak menyampaikan informasi mengenai jalur yang akan dilalui oleh para peserta, sehingga tidak dapat menggambarkan sejauh apa jalut yang akan dialui, hal ini penting disampaikan karena kegiatan ini merupakan kegiatan olahraga yang harus disesuaikan dengan kondisi badan. Informasi mengenai jam acara dimulaipun tidak tersampaikan memalui publikasi poster "Bandung Lautan Sepeda" yang dipublikasikan ini sehingga para peserta tidak dapat mengetahui informasi mengenai tepatnya pukul berapa acara dimulai dan hingga kapan acara berlangsung.

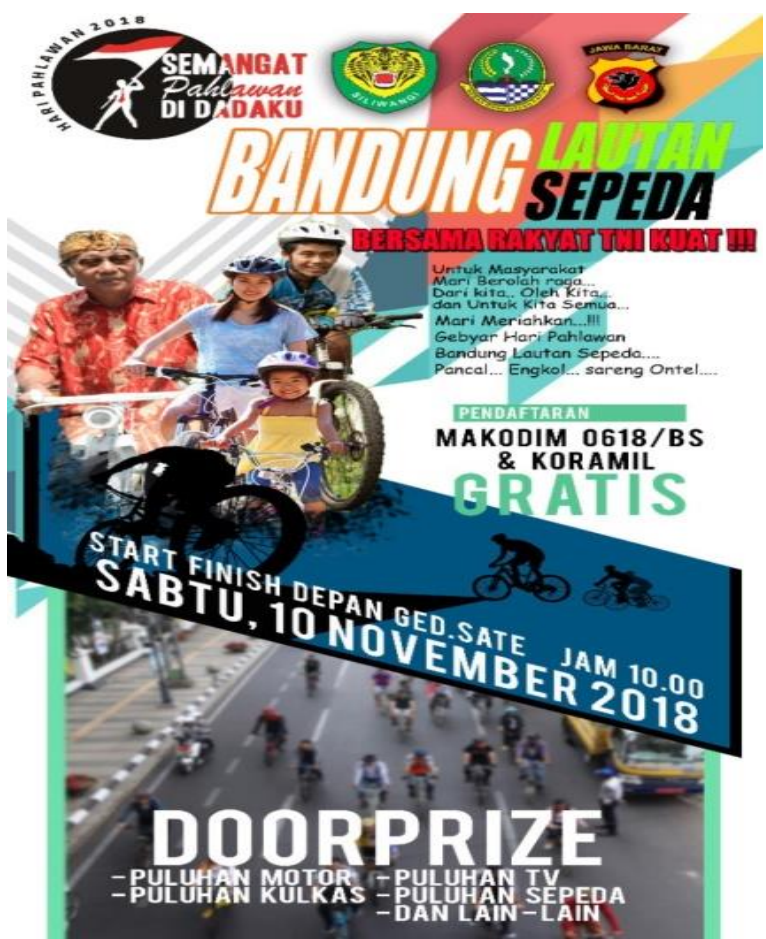

Gambar 2. Poster Publikasi Bandung Lautan Sepeda 2

Selanjutnya terdapat poster publikasi yang kembali disebarkan oleh pihak penyelenggara "Bandung Lautan Sepeda". Pada aspek pesan yang disampaikan pada poster ini lebih banyak informasi yang ingin disampaikan kepada target sasaran meskipun sebagian besar informasi yang disampaikan sama. Informasi yang kurang pada poster sebelumya. Pada poster publikasi ini dicantumkan informasi mengenai waktu acara yaitu pukuk 10 pagi. Selain itu, informasi yang disampaikan mengenai jalur lebih jelas yaitu garis mulai dan selesai berlokasi di Gedung Sate. Akan tetapi informasi yang belum didapatkan adalah jalur yang dilalui peserta selama bersepeda di kegiatan ini.

Kejelasan mengenai informasi pendaftaran pesertapun dicantumkan pada poster ini dimana peserta tidak dipungut biaya apapun untuk mengikuti kegiatan ini dan informasi tambahan mengenai hadiah yang bisa didapatkan pesertapun dipublikasikan melalui poster publikasi ini. Hal yang menarik pada publikasi ini adalah adanya kutipan bahasa daerah yaitu "Pancal, Engkol, Sareng Ontel" yang berarti mengajak masyarakat untuk bersepeda berkeliling menggunakan ontel, yaitu dengan tujuan untuk mengingatkan masyarakat pada Indonesia zaman dahulu dalam memperingati Hari Pahlawan ini.

Pada acara "Bandung Lautan Sepeda", Sekretariat Daerah Provinsi Jawa Barat juga membina hubungan yang baik dan bekerjasama dengan masyarakat di sekitar instansi dimana nantinya dapat menjadi pendukung hubungan baik antara keduanya baik dengan publik internal dan eksternal. "Bandung Lautan Sepeda" ini juga dapat dikatakan sebagai Special Events and Public Participant, yaitu aktivitas langsung yang melibatkan publik dan dilakukan oleh Public Relations untuk menjalin interaksi secara organisasi/perusahaan dengan publik oleh Setda Jabar.

Menurut (Goldblatt, 2014) jenis acara yaitu meetings and conferences yang berupa pertemuan antara pejabat pemerintah yang memberikan kesempatan networking bagi instansi yang berbentuk ramah tamah, atau interaksi antara peserta/publik kegiatan tersebut dan upacara peringatan serta sebuah peristiwa yang umumnya ada di masyarakat yang biasanya diadakan setiap tahun social life cycle event. Maka Biro Humas dan Protokol Sekretariat Daerah Provinsi Jawa Barat menjalankan salah satu kegiatan kehumasan.

Peran Humas dalam melaksanakan tugas pada acara Bandung Lautan Sepeda ini dapat dikategorikan dalam strategi Public Relations menurut (Ruslan, 2008) yaitu publikasi dan event. Dalam kegiatan publikasi humas dan protokol Setda Jabar menyebarkan informasi melalui media yang telah ditetapkan terkait tentang kegiatan sebelum dan sesudah acara.agar informasi terkait acara lebih luas tersebar. Selain itu Bandung Lautan Sepeda adalah salah satu kegiatan Humas dan Protokol Setda Jabar yaitu bertujuan untuk mendekatkan diri ke publik. Bandung Lautan Sepeda ini merupakan sebuah special event 
yang diselenggarakan secara khusus di luar program rutin.

Peranan Public Relations menurut (Ruslan, 2008), adalah sebagai komunikator atau penghubung dan membina hubungan yang positif. Hal ini dilakukan Humas dan Protokol Setda Jabar pada pertemuan yang dihadiri oleh instansi-instansi yang berkaitan dengan acara "Bandung Lautan Sepeda". Komunikasi yang dilakukan di setiap pertemuan tersebut adalah untuk menjalankan koordinasi kegiatan "Bandung Lautan Sepeda". Aktivitas Humas dan Protokol Setda Jabar pada "Bandung Lautan Sepeda" ini selaras dengan aktivitas PR yang dikategorikan oleh (Saputra \& Nasrullah, 2011), yaitu untuk community relations, public affairs dan special events and public participant. Humas dan Protokol Setda Jabar melakukan pembinaan dan komunikasi di masyarakat sekitar instansi di antaranya adalah lembaga-lembaga yang bekerjasama dengan Setda yaitu Kodam III Siliwangi dan Polda Jabar.

Membina hubungan baik juga dilakukan dengan pihak internal instansi yaitu para pegawai negeri sipil yang bekerja di Sekterariat Daerah Pemerintah Provinsi Jawa Barat, dimana para pegawai diajak untuk terlibat dan bertugas pada penyelenggaraan "Bandung Lautan Sepeda". Hal-hal untuk menarik keikut sertaan para pegawai untuk acara tersebutpun dilakukan salah satunya dengan membagikan kupon hadiah yang akan diundi bagi para peserta "Bandung Lautan Sepeda". Dalam kegiatan "Bandung Lautan Sepeda" pun masyarakat beraktivitas langsung dengan para pejabat daerah yang melibatkan publik.

Pada acara "Bandung Lautan Sepeda" Biro Humas dan Protokol Pemprov Jabar memiliki peran untuk memegang koordinasi terkait susunan acara, pengendalian, fasilitasi dan pelaksanaan fungsi penunjang urusan pemerintahan meliputi pelayanan media dan informasi, publikasi, peliputan dan dokumentasi serta keprotokolan. Pemprov Jabar sebagai instansi pemerintahan tertinggi di Jawa Barat memiliki andil utama dalam meraih kepercayaan publik atau masyarakatnya. Pada Biro Humas dan Protokol Pemprov Jabar terdapat fungsi pelayanan informasi sebagaimana tercantum pada tugas pokoknya.

Pengunaan media merupakan salah satu strategi yang digunakan dalam memberikan informasi kepada publik dan target sasaran acara "Bandung Lautan Sepeda". Menurut (Anggoro, 2008), dalam Public Relations terdapat media yang dapat menunjang kerja dalam menjangkau khalayak dalam maupun luar perusahaan. Media tersebut terbagi menjadi dua seperti media internal dan media eksternal. Pada kegiatan "Bandung Lautan Sepeda", Biro Humas dan Protokol menyasar target internal dan eksternal dimana target internal adalah karyawan Sekretariat Daerah Provinsi Jawa Barat dan target eksternalnya adalah masyarakat yang tidak dibatasi wilayah dan umur. Dalam penyebaran informasi tentang acara tersebut media yang digunakan untuk penyebaran informasi di internal adalah menggunakan media siaran umum menggunakan pengeras suara, yang disiarkan oleh Sub Bagian Publikasi Sekretariat Daerah Provinsi Jawa Barat dengan bekerjasama dengan Sub Penata Acara Keprotokolan untuk menyiarkan informasi kepada para pekerja yang berada di Gedung Sekretariat Pemerintah Provinsi Jawa Barat. Informasi yang disiarkan terkait waktu, runtutan acara, ketentuan fasilitas publik yang akan digunakan selama acara dan menghimbau agar dapat turut mengikuti acara ini, informasi tersebut disiarkan pada jsm mendekati kepulangan para karyawan.

Publikasi media eksternal yang digunakan guna menyebarkan informasi terkait acara "Bandung Lautan Sepeda" melalui media audiovisual dan internet yang diarahkan kepada khalayak yang sudah ditentukan. Tujuan dari media ini adalah untuk menjangkau khalayak dalam rangka mengkomunikasikan pesan khusus demi mencapai tujuan penyampaian pesan dan kontribusi masyarakat. Penggunaan internet yang dipakai meliputi Social Media, Website, dam Blog.

Biro Humas dan Protokol Sekretariat Pemprov Jabar memiliki platform berupa grup Whats App yang beranggotakan media-media di Jawa Barat yang digunakan untuk memberikan informasi terkait acara. Selain itu penyebaran informasi ini juga bekerjasama dengan Kodam III Siliwangi. Berdasarkan media yang menyebarkan informasi terkait acara "Bandung Lautan Sepeda", penyampaian informasi dilakukan dari sebelum acara hingga acara tersebut selesai. Media-media yang membagikan informasi dan proses sebelum acara di antaranya: Pada kegiatan Bandung Lautan Sepeda pihak penyelenggara menggunakan media below the line dan above the line. Pada media yang ditargetkan difokuskan kepada media lokal Bandung hal tersebut didasari lokasi pelaksanaan acara yang bertempat di Gedung Sate sehingga dirasa mudah untuk mencari peserta yang ditargetkan untuk mengikuti acara BLS. 
Tabel 1. Publikasi Pada Media Daring

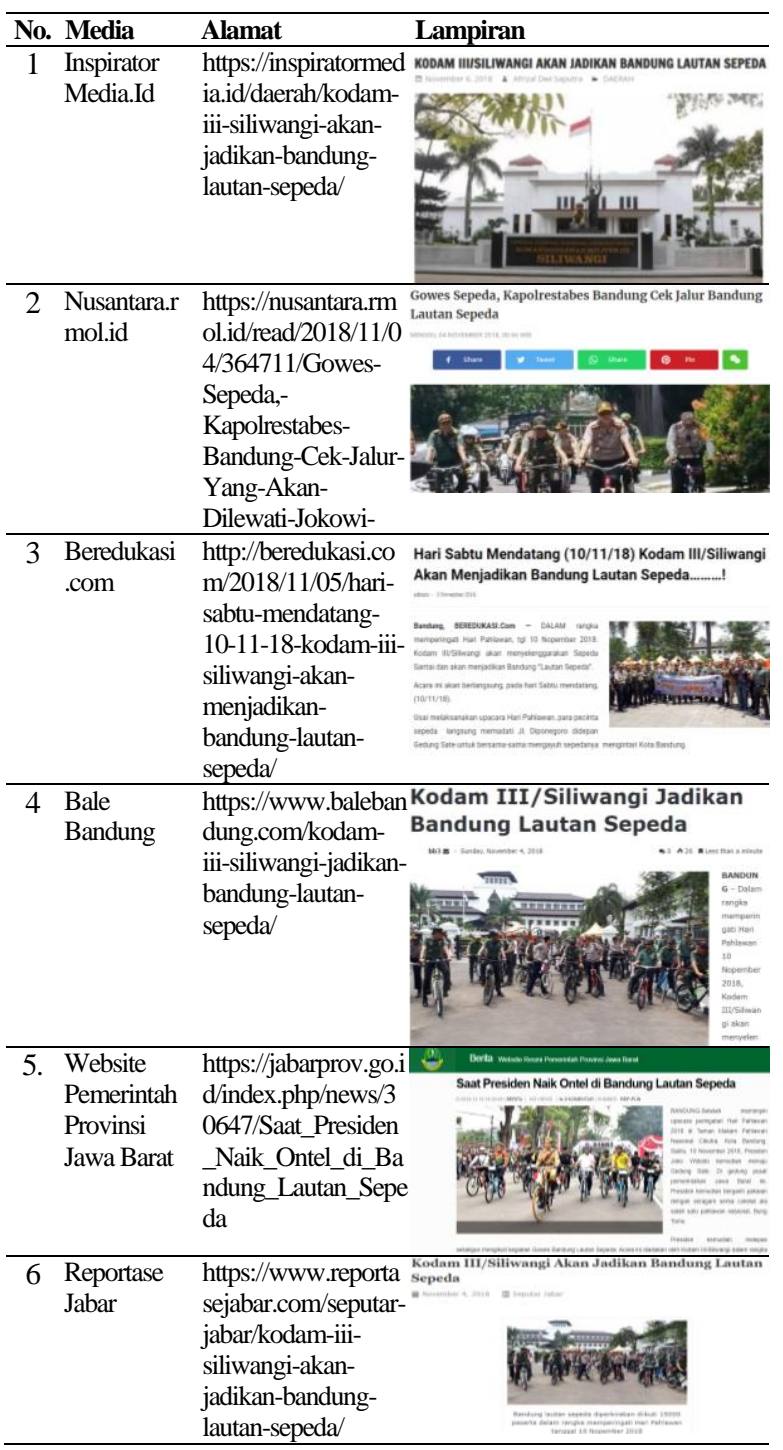

Informasi yang disampaikan sebelum acara tersebut berlangsung yaitu seputar jalur yang akan dilewati oleh para peserta serta tema dari kegiatan Bandung Lautan Sepeda yaitu memperingati Hari Pahlawan. Salah satu media PR FM News menyiarkan berita mengenai infomasi pelayanan publik terkait acara Bandung Lautan sepeda untuk menghimbau dan khususnya memberikan informasi kepada pengguna jalan raya terkait pengunaan dan penutupan jalan. Sedangkan publikasi setelah acara, para media yang menyiarkan berita lebih fokus kepada antusias warga dan para tokoh nasional terutama Presiden Jokowi dan Gubernur Ridwan Kamil.

Penyebaran informasi yang digunakan Sekretariat Daerah Pemprov mengenai acara Bandung Lautan Sepeda juga didukung oleh para pengguna dan penyedia media online, diantaranya: pada pemberitaan tersebut memperlihatkan antusias masyarakat dalam mengikuti kegiatan Bandung Lautan Sepeda.
Tabel 2. Publikasi Pada Media Massa

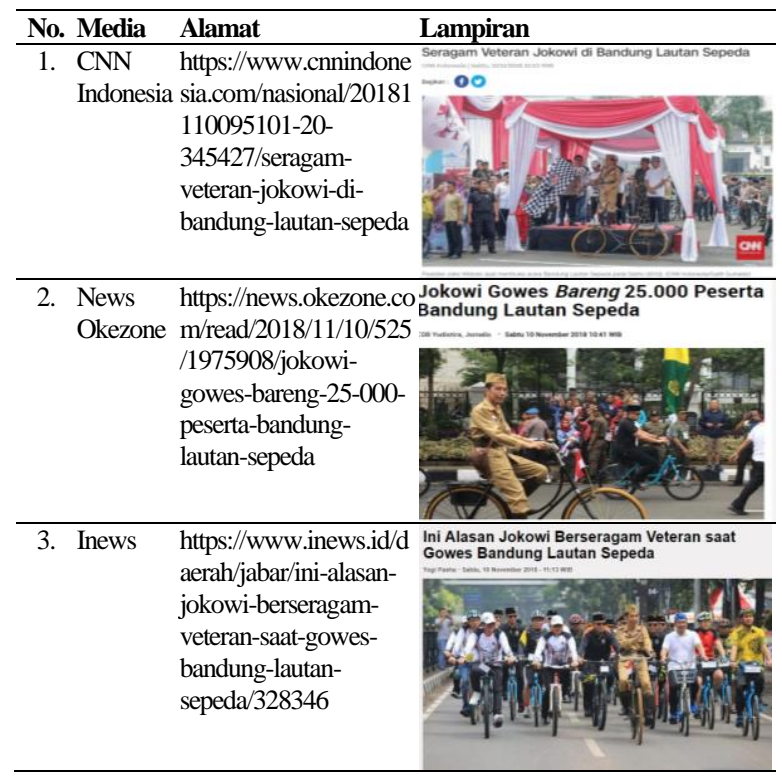

Tabel 3. Publikasi Pada Media Sosial

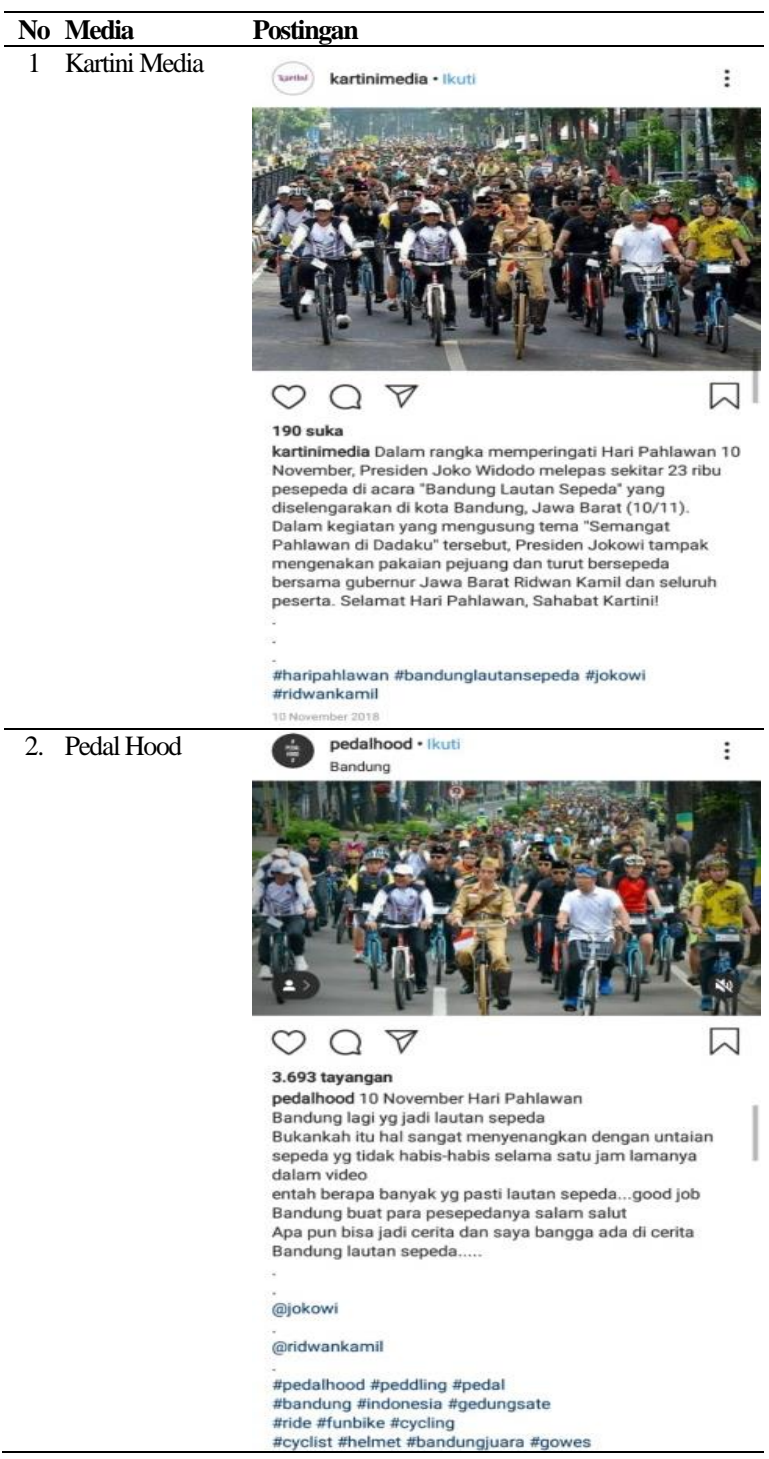



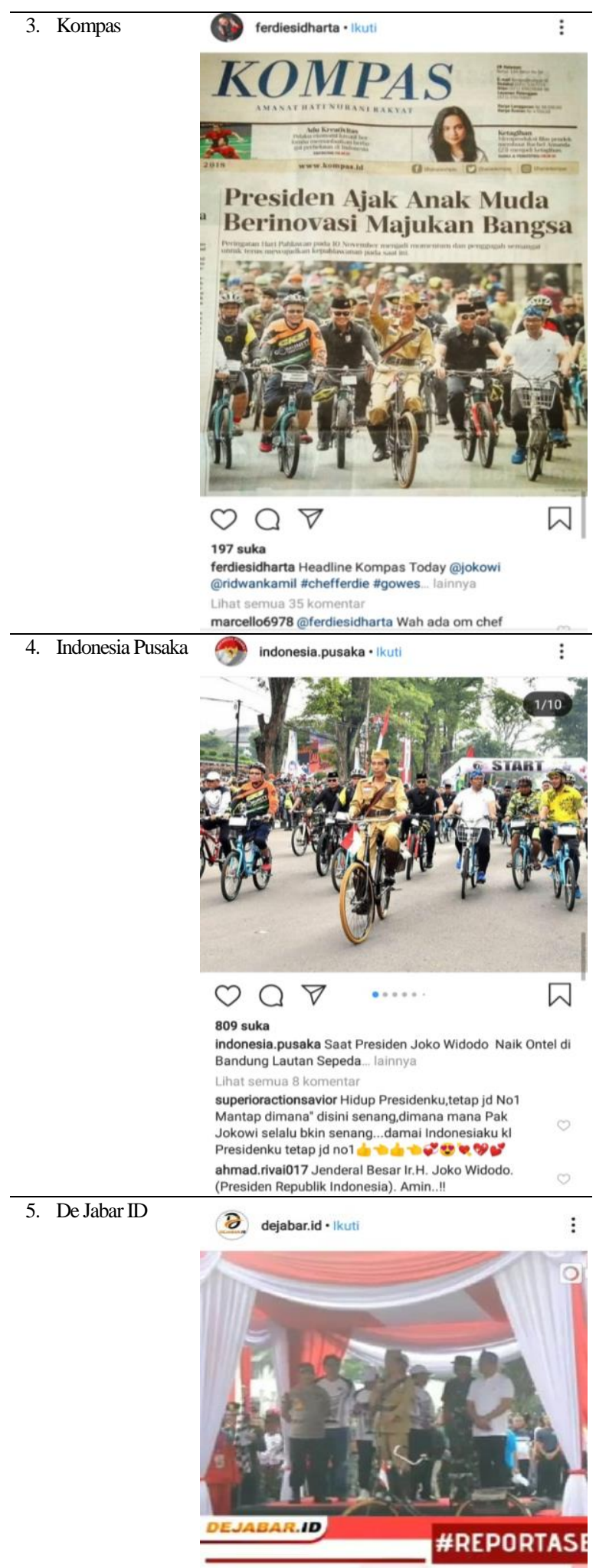

Jokowi dengan resmi membuka kegiatan 'Bandung Lautan Sepeda', dalam rangkaian kegiatan peringatan Hari Pahlawan bersame puluhan ribu warga Bandung, di lingkungan Kodam III Sillwangi. Kota Bandung Sabtu
(10/11/2018)

$\bigcirc \bigcirc \nabla$

116 tayangan

dejabar.id Di Bandung Lautan Sepeda, Presiden Jokowi (@jokowi) mengenakan pakaian safari warna cokelat, lengkap dengan topi dan sepatu kulit panjang. Di bagian

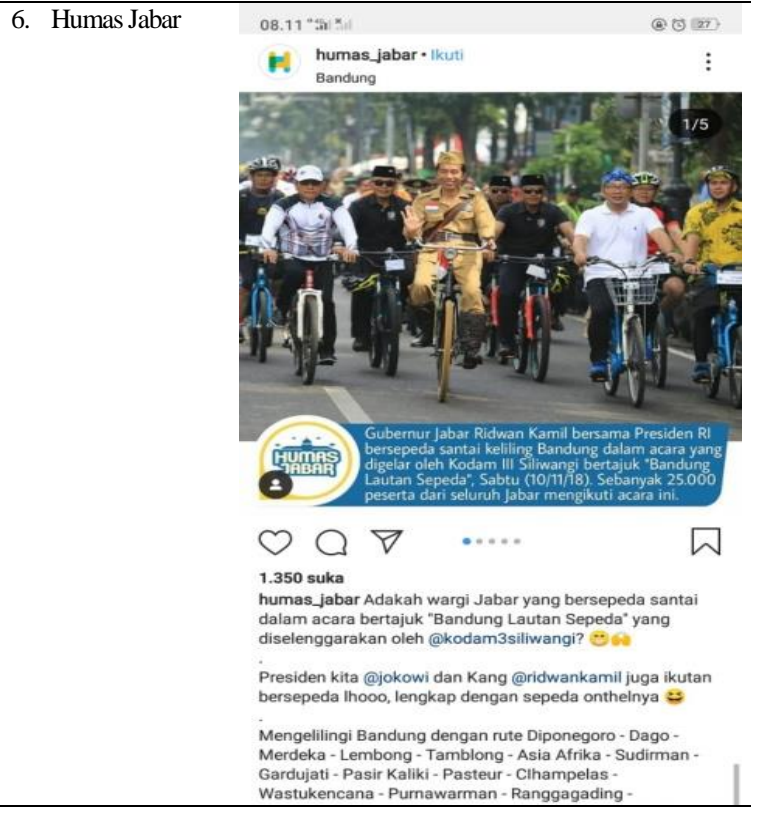

Pada setiap pertemuan untuk mendiskusikan acara tersebut Biro Humas dan Protokol Pemprov Jabar merepresentasikan citra pemerintahan provinsi Jawa Barat dan mensosialisasikan serta menghimbau masyarakat sekitar untuk memiliki jiwa nasionalisem dan pembangunan. Sebagai salah satu Humas pemerintahan yang selalu mendapatkan penghargaan di ajang nasional, peran publikasi juga dilakukan oleh Humas Jabar itu sendiri melalui instagram resmi milik humas Jabar yang menjelaskan runtutan acara tersebut serta jumlah peserta yang mengikuti acara tersebut. Hal ini disesuaikan dengan pemetaan yang telah ditentukan oleh Biro Humas dan Protokol Sekretariat Daerah Provinsi Jawa Barat.

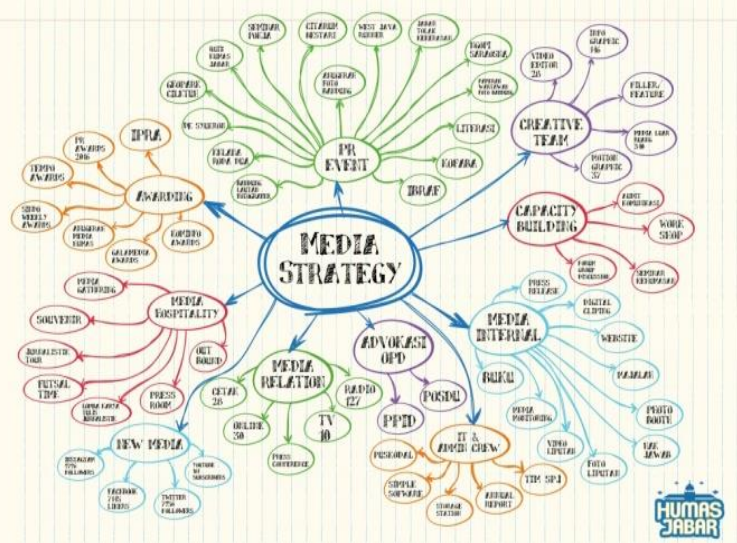

Gambar 1. Strategi Media Humas Setda Jabar

Pada pemetaan media strategy tersebut target dari media relations yang dipetakan tidak memiliki limitasi sehingga memungkinkan untuk menjalin relasi yang lebih luas. Melalui kegiatan Bandung Lautan Sepeda Biro Humas dan Protokol Setda Jabar juga melakukan tahapan fact finding untuk mengetahui apa 
yang sedang banyak diperbincangkan publik dan memilih media dan waktu yang tepat untuk menjalankan sebuah program.

Setelah mengetahui fakta-fakta dan menghimpunnya menjadi sebuah informasi, Biro Humas dan Protokol Setda Jabar menyusun poin yang akan dijadikan strategi dalam pelaksanaan program berdasarkan data dan fakta yang ada, yaitu Take Action and Communicating. tahap ini dapat juga diartikan sebagai tahap pengkomunikasian dari rencana yang sudah dibuat. Jadi secara tidak langsung pada tahap ini merupakan tahap pengeksekusian dari data, fakta dan rencana yang ada yang nantinya akan dikomunikasikan ke publik melalui publikasi di berbagai media sesuai dengan target publik internal maupun eksternal yang telah ditentukan.

Pada kegiaan "Bandung Lautan Sepeda" Humas dan Protokol Sekretariat Daerah Provinsi Jawa Barat menggunakan media below the line untuk publikasi, dimana media ini tidak membutuhkan biaya promosi. Word of Mouth dapat dikategorikan sebagai media below the line. Secara definisi Word of Mouth memiliki 3 indikator yaitu volume, valence, dan content. Volume merupakan pihak yang menyampaikan pesan yaitu humas dan protokol Setda Jabar yang membicarakan informasi tersebut yang berisi pesan positif yaitu kegiatan Bandung Lautan Sepeda yang berisi fakta-fakta. Pada proses penyampain tersebutpun secara langsung menggambarkan content yang terkait pada kegiatan Bandung Lautan Sepeda yaitu lembaga terkait Setda Jabar, Polda Jabar dan Kodam III Siliwangi.

Word of Mouth sendiri jika didefinisikan adalah pembicaraan secara langsung dimana antara orang ke orang berkomunikasi sebagai penerima dan komunikator. Dalam kaitannya dengan word of mouth, (Kotler, 2000) menyatakan bahwa saluran komunikasi personal dalam ucapan atau perkataan dari mulut ke mulut bisa menjadi metode promosi yang efektif karena pada umumnya disampaikan dari konsumen oleh konsumen dan untuk konsumen, sehingga konsumen yang puas dapat menjadi media iklan bagi perusahaan. Pada kegiatan "Bandung Lautan Sepeda" ini pun tidak dianggarkan biaya promosi untuk pemasangan iklan pada media lini tertentu, informasi yang disampaikan oleh pihak panitia disebarkan melalui prmbicaraan dan masyarakat sekitar yang dikenal.

Alasan yang membuat word of mouth dapat menjadi sumber informasi yang kuat dalam mempengaruhi yaitu WOM dapat dijadikan sumber informasi yang jujur karena berdasarkan pengalaman si penyebar pesan karena melalui pendekatan individu yang dianggap kredibel dan tidak ada kaitannya dengan instansi dan selain itu kekuatan word of mouth merupakan upaya promosi dari pengalaman seseorang yang disampaikan secara lisan (Gumilar \& Zulfan, 2014). Berdasarkan (C.P., 2013) menunjukkan bahwa pengalaman kedekatan menggunakan suatu produk atau jasa dapat menjadi salah satu penyebab orang loyal terhadap merek dan berujung melakukan word of mouth yang dapat membangkitkan tanggapan emosional dan memberikan inspirasi.

Pada kegiatan "Bandung Lautan Sepeda" ini salah satu pesan komunikasi yang ingin disampaikan adalah untuk menjaga semangat juang para masyarakat sekitar semangat pahlawan di dadaku, yang bertujuan untuk menyampaikan pesan Semangat untuk membangun negara, untuk terus membangun negara. Sehingga mengajak dan melibatkan masyarakat, komunitas dan para pegawai dalam kegiatannya.

Dalam kegiatan "Bandung Lautan Sepeda" ini pesanpesan yang dikomunikasikanpun dapat menekan biaya instansi melalui kegiatan Humas dan Protokol Setda Jabar dimana media yang digunakan adalah media word of mouth yaitu penyebaran informasi dari mulut ke mulut.

\section{SIMPULAN}

Isi pesan yang disampaikan pada acara "Bandung Lautan Sepeda" bersifat persuasif yaitu mengajak masyarakat sekitar untuk hidup sehat dan bersama pemerintah menjaga semangat juang untuk membangun negara. Pesan persuasif tersebut disampaikan melalui kalimat pada poster yang berupa ajakan.

Media publikasi yang digunakan dalam kegiatan "Bandung Lautan Sepeda" berfokus pada media below the line dimana penyebaran informasi dilakukan melalui word of mouth melalui pembicaraan dari mulut ke mulut, informasi disebarkan kepada masyarakat, pegawai pemerintahan, dan lembaga sekitar instansi.

\section{SARAN}

Isi pesan yang dipublikasikan melalui media massa mudah dipahami dan dapat menarik perhatian target sasaran yaitu masyarakat Bandung dengan penggunaan kalimat ajakan berbahasa Sunda. Akan tetapi isi pesan akan lebih mudah dipahami jika menggunakan bahasa sunda sehari-hari sehingga dapat dipahami juga oleh masyarakat di luar Jawa Barat. 
Sebaiknya pihak penyelenggara dapat memaksimalkan penggunaan media above the line untuk mempublikasikan acara. Media yang digunakan dapat disebarakan melalui papan iklan di sekitar Bandung, seperti televisi, megatron dan billboard.

\section{DAFTAR PUSTAKA}

Anggoro, L. (2008). Teori dan Profesi Kehumasan Serta Aplikasinya di Indonesia. Jakarta: PT. Bumi Aksara.

Ardianto, E. (2014). Metodologi penelitian untuk public relations kuantitatif dan kualitatif. Bandung: PT Simbiosa Rekatama Media.

Awaliah, N. (2012). Event sebagai ajang promosi bagi perusahaan jasa. Jurnal Komunikologi, 9(1), 23-31.

C.P., R.P.A. (2013). Pengaruh Pengalaman Menggunakan Produk dan Persepsi Konsumen Berdasarkan Kelompok Referensi terhadap Kesediaan Konsumen untuk Melakukan Word Of Mouth. Jurnal Ilmu Komunikasi, 10(1), 25-40.

Effendy, O. U. (2002). Ilmu Komunikasi Teori dan Praktek. Bandung: PT Remaja Rosdakarya.

Goenawan, F. (2008). Nilai dan Gaya Hidup Masyarakat Di Dalam Media. Jurnal Scriptura, 2(2), 183-190.

Goldblatt, J. (2014). Special events: creating and sustaining a new world for celebration. New Jersey: John Willey and Son, Inc.
Gumilar, G., \& Zulfan, I. (2014). Penggunaan Media Massa Dan Internet Sebagai. Jurnal Kajian Komunikasi, 2(1), 85-92.

Herdiana, D., \& Khoiruddin. (2016). Peran dan strategi humas dalam pembentukan citra perguruan tinggi islam. Jurnal ANIDA, 15(2), 317-338.

Herlina, S. (2015). Strategi komunikasi humas dalam membentuk citra pemerintahan di kota malang. Jurnal Ilmu Sosial Dan Ilmu Politik, 4(3), 493500.

Kotler, P. (2000). Manajemen pemasaran: analisis, perencanaan, implementasi dan kontrol (8th ed.). Jakarta: Prenhallindo.

Kotler, P., \& Amstrong, G. (2006). Prinsip-prinsip pemasaran (12th ed.). Jakarta: PT. Erlangga.

Noor, J. (2011). Metodelogi Penelitian: Skripsi, Tesis, Disertasi, dan Karya Ilmiah. Jakarta: PT. Kencana Prenada Media Group.

Putra, I. G. N. (1999). Tantangan Public Relations dalam Sektor Publik. Jkap.

Ruslan, R. (2008). Manajemen Public Relatoins \& Media Komunikasi. Jakarta: PT. Raja Grafindo Persada.

Saputra, W., \& Nasrullah, R. (2011). Public Relations 2.0: Teori dan Praktik Public Relations di Era Cyber. Depok: Gramata Publishing.

Soemirat, S., \& Ardianto, E. (2007). Dasar-dasar public relations. Bandung: PT Simbiosa Rekatama Media.

Sugiyono. (2010). Metode Penelitian Kuantitatif, Kualitatif dan R\&D. Bandung: Alfabeta. 